\title{
Age-wise seroprevalence of hepatitis $C$ virus infection in clinically suspected infectious hepatitis patients attending a tertiary care hospital in Delhi
}

\section{Monika Rajani,} Manoj Jais

Department of Microbiology, Lady Hardinge Medical College, New Delhi, India

Address for the Correspondence: Dr. Monika Rajani, House No. 789, Sector 19, Indira Nagar, Lucknow - 226016 , Uttar Pradesh, India. E-mail: drmrajani@rediffmail.com

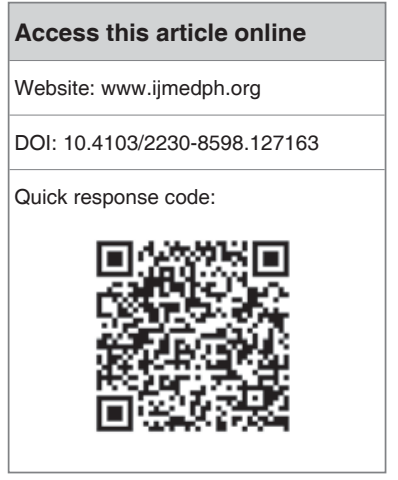

Introduction: Hepatitis $C$ is a major public health problem globally. There are limited studies on age and sex related prevalence of hepatitis $\mathrm{C}$ virus (HCV). As hepatitis $\mathrm{C}$ is a preventable disease, the burden of the disease could be reduced to a significant extent if its seroprevalence is better known in different age groups. Objective: The objective of this study is to determine age-wise seroprevalence of HCV in clinically suspected infectious hepatitis patients. Materials and Methods: This prospective study was conducted in the Department of Microbiology at Lady Hardinge Medical College, New Delhi over a period of one year from January 2008 to December 2008. All the serum samples taken from subjects (600 study and 200 control) were tested for immunoglobulin M (IgM) anti HCV using commercially available enzyme linked immunosorbent assay kit. Study group consisted of patients with clinically suspected acute infectious hepatitis while the control group had age and sex matched patients showing no clinical evidence of acute infectious hepatitis. Results: Overall 33 $(5.5 \%)$ samples tested positive for IgM anti HCV in the study group while $3(1.5 \%)$ samples tested positive in the control group. On analyzing age-wise seropositivity, it was found that maximum seropositivity of IgM anti HCV was in 11-20 years of age group in the study group (9\%) followed by $21-30$ years $(6.1 \%), 0-10$ years $(5.1 \%)$ and $>40$ years $(3.7 \%)$ of age. On the other hand in the control group, the maximum seropositivity of IgM anti HCV was seen in 0-10 years (2.8\%) followed by $11-20$ years $(2.7 \%)$. Conclusions: HCV infection is predominantly a disease of young adults, which is due to cumulative risk of exposure with increasing age. However infection in children is explained by the mother to baby transmission. Most of the $\mathrm{HCV}$ infected patients are unaware of their clinical status and hence the disease may be under reported.

Key words: Enzyme linked immunosorbent assay kit, hepatitis $C$ virus, immunoglobulin $\mathrm{M}$ anti hepatitis $\mathrm{C}$ virus, seroprevalence

\section{INTRODUCTION}

Hepatitis $\mathrm{C}$ virus (HCV) infection is a major public health concern. ${ }^{[1]} \mathrm{It}$ is a single stranded ribonucleic acid virus and is the most common cause of post transfusion hepatitis. ${ }^{[2]} \mathrm{It}$ is estimated that 200 million people world-wide are infected with $\mathrm{HCV} \cdot{ }^{[3]} \mathrm{HCV}$ is gradually being recognized as a major health problem in developing countries. ${ }^{[4]}$ World Health Organization estimates that there are 10-24 million $\mathrm{HCV}$ infected persons living in India. ${ }^{[5]}$ The seroprevalence of HCV in apparently healthy people in India ranges from $1.5 \%$ to $4 \%{ }^{[6-9]}$ The seroprevalence ranges from $3 \%$ to $12 \%$ in patients suspected of acute viral hepatitis. ${ }^{[8,10,11]}$

Certain population groups such as injecting drug users, recipients of unscreened blood products, patients in hemodialysis centers, organ transplant patients and individuals with increased promiscuity tend to have a higher probability of $\mathrm{HCV}$ transmission. ${ }^{[4]} \mathrm{HCV}$ can also be transmitted from mother to baby. ${ }^{[4]}$

About $75 \%$ of infections are sub clinical and are revealed incidentally by abnormal liver function test and/or seropositivity. ${ }^{[12]}$ Complications include chronic hepatitis (70\%), cirrhosis (20-30\%), hepatocellular 
carcinoma and liver failure. ${ }^{[13]}$ The prevalence of HCV related viral hepatitis still remains debatable in developing and developed countries. ${ }^{[6-11]}$ There are few prevalence studies from urban northern India. ${ }^{[6-11]}$ There are very limited studies on age and sex related prevalence of $\mathrm{HCV}$. As hepatitis $\mathrm{C}$ is a preventable disease, the burden of the disease could be reduced to a significant extent, if its seroprevalence is better known in different age groups.

\section{MATERIALS AND METHODS}

This prospective study was conducted in the Department of Microbiology at Lady Hardinge Medical College, New Delhi, which is a tertiary care hospital in urban Northern India, over a period of 1 year from January 2008 to December 2008. Subjects were divided into two groups. Group I was the study group of 600 patients with clinically suspected acute infectious hepatitis attending the out-patient department of various specialties in Kalawati Saran and Smt. Sucheta Kriplani Hospital attached to Lady Hardinge Medical College. Group II was the control group with 200 age and sex matched patients showing no clinical evidence of acute infectious hepatitis.

\section{Inclusion criteria}

- Recent onset of jaundice (less than 6 months), defined by serum bilirubin level $>2.5 \mathrm{mg} / \mathrm{dl}$ and/or increase in serum transaminases more than 5 times the upper limit of normal.

- Fever in the absence of chronic liver disease or past history of jaundice.

\section{Exclusion criteria}

- History of chronic liver disease or past history of jaundice with duration of illness more than 6 months.

- Acute fatty liver/alcoholic hepatitis/intrahepatic cholestasis.

All the serum samples taken from subjects (study and control group) were tested for immunoglobulin $\mathrm{M}(\operatorname{IgM})$ anti HCV using commercially available enzyme linked immunosorbent assay kit (ELISA; Biokit, Barcelona, Spain).

\section{RESULTS}

The study and control group were divided age-wise into 0-10 years, 11-20 years, 21-30 years, 31-40 years and $>40$ years. The study group comprised of 362 male and 238 female patients. The overall male to female ratio was $1.5: 1$ and thus a male preponderance was seen in the study group. The control group $(n=200)$ comprised of 121 males and 79 females with overall male to female ratio of 1.5:1. The mean age in the study group was $20.2 \pm 15.2$ years while in the control group it was $19.65 \pm 14.8$ years. Overall 33 (5.5\%) serum samples tested positive for $\operatorname{IgM}$ anti $\mathrm{HCV}$ in the study group while $3(1.5 \%)$ tested positive in the control group.

Maximum seropositivity to IgM anti $\mathrm{HCV}$ was seen in 11-20 years in the study group (9\%) followed by $21-30$ years $(6.1 \%), 0-10$ years $(5.1 \%)$ and $>40$ years $(3.7 \%)$ of age. Although in the control group, the maximum seropositivity to $\mathrm{IgM}$ anti $\mathrm{HCV}$ was seen in $0-10$ years $(2.8 \%)$ followed by $11-20$ years $(2.7 \%)$. The difference in seropositivity in the study and control group was statistically insignificant in all the age groups $(P>0.05)$ [Table 1].

\section{DISCUSSION}

The study recorded an overall seroprevalence rate of $\mathrm{HCV}$ as $5.5 \%$ in the study and $1.5 \%$ in the control group. Seroprevalances of IgM anti HCV recorded by different authors in and around Delhi ranges from $3 \%$ to $12 \% \cdot{ }^{[8,10,11,14-16]}$ Kar et al. reviewed 133 patients with acute viral hepatitis and recorded the overall seroprevalence of IgM anti $\mathrm{HCV}$ as $12 \% .{ }^{[8]}$ Kaur et al. recorded the seropositivity of IgM anti HCV in 306 patients with acute viral hepatitis as $3.3 \% .^{[15]}$

HCV seropositivity trends from 1997 to 2002 showed a gradual decline from $12 \%$ to $3.3 \%$, but in last few years it is on an increasing trend. ${ }^{[8,14-16]}$ The decline was attributed to ban by Supreme Court of India on professional blood donations. ${ }^{[17,18]}$ Professional blood donation was an accepted practice until 1997. ${ }^{[17]}$ This ban curtailed the transmission of HCV through unscreened blood donations. The government of India has also implemented quality control of blood banks with stringent blood transfusion safety measures and effective licensing system. ${ }^{[17,18]}$ All these measures might have contributed to decline in $\mathrm{HCV}$ seroprevalence during those years.

During last few years, HCV seroprevalence is again increasing partly explained by a rapid increase in the population of Delhi burdening the health-care system. Delhi is also experiencing a heavy load of the migrant population due to tourism and industrial activities. Socio-economically compromised population of Delhi has

\begin{tabular}{|c|c|c|c|c|c|}
\hline \multirow[t]{2}{*}{ Age group } & \multicolumn{2}{|c|}{ Study group $(n=600)$} & \multicolumn{2}{|c|}{ Control group $(n=200)$} & \multirow[t]{2}{*}{$P$ value* } \\
\hline & Sample tested & Sample positive (\%) & Sample tested & Sample positive (\%) & \\
\hline $0-10$ years & 214 & $11(5.1)$ & 71 & $2(2.8)$ & 0.372 \\
\hline $11-20$ years & 110 & $10(9)$ & 36 & $1(2.7)$ & 0.185 \\
\hline $21-30$ years & 130 & $8(6.1)$ & 43 & 0 & 0.125 \\
\hline $31-40$ years & 67 & $1(1.4)$ & 22 & 0 & 0.546 \\
\hline$>40$ years & 79 & $3(3.7)$ & 28 & 0 & 0.270 \\
\hline Total & 600 & $33(5.5)$ & 200 & $3(1.5)$ & 0.018 \\
\hline
\end{tabular}

$* P$ value $<0.05=$ Significant, $\mathrm{HCV}=$ Hepatitis $C$ virus 
poor access to health information and quality health-care. Unsafe injecting practices, intravenous drug abuse and unsafe sex practices, all have a contributory effect on the overall seroprevalence of $\mathrm{HCV}^{[19]}$ The seropositivity rate of IgM anti HCV among the general population in our study $(1.5 \%)$ was comparable with other studies $(1.03-1.7 \%) .^{[18,20-22]}$ Pahuja et al. found seroprevalence of $0.66 \%$ in a hospital based study with 4014 subjects. ${ }^{[20]}$

\section{Trends of HCV in different age groups}

The maximum seropositivity was seen in $11-20$ years $(9 \%)$ followed by $21-30$ years $(6.1 \%), 0-10$ years $(5.1 \%)$ and $>40$ years $(3.5 \%)$. Various studies have demonstrated high seroprevalences of IgM anti HCV among the adult population. ${ }^{[21,23,24]}$ Bhattacharya et al. found seroprevalance rate of $8.5 \%$ in 661 patients with acute viral hepatitis within 20-39 years of age group. ${ }^{[23]}$ Devi et al. found maximum seropositivity in the age group of $30-40$ years $(46.6 \%) .{ }^{[25]}$

The high prevalence rate seen in young adults (15-40 years) is due to cumulative risk of exposure in these age groups. $\mathrm{HCV}$ is one of the major etiological agents of parenterally acquired hepatitis and is responsible for most cases of transfusion associated hepatitis. HCV is usually transmitted by sharing infected needles, unsafe transfusion practices and accidental exposures. ${ }^{[19]}$ Some people acquire infection through sexual transmission. All blood donations are still not compulsorily screened for HCV in India. In past few years contaminated needles and syringes have resulted in numerous outbreaks across the country. ${ }^{[26]}$ Adults are at higher exposure risk due to unsafe practices. ${ }^{[27]}$ Tattooing could be an added risk factor. ${ }^{[28]}$

In the control group, the maximum seropositivity was seen in $0-10$ years $(2.8 \%)$ followed by $11-20$ years of age $(2.7 \%)$. The differences in trends of $\mathrm{HCV}$ could be attributed to maximum patients from these age groups. The reason could be a separate pediatric hospital with an independent thalassemia ward at our institution. Many samples were received from this ward for routine screening of children diagnosed with thalassemia and other hemoglobinopathies. Such patients are at an increased risk of HCV transmission due to unsafe injecting practices. Mother to baby transmission is another mode of $\mathrm{HCV}$ transmission. Stringent screening of blood products introduced during the early 1990's had minimized this mode of HCV acquisition leaving vertical transmission from infected mothers as the predominant mode of infection in children. ${ }^{[27]}$

\section{CONCLUSION}

HCV infection is predominantly a disease of young adults, which is due to cumulative risk of exposure with age. However, few cases seen in children aged less than ten years resulted from mother to baby transmission. HCV infection still remains a burden on the health-care system world-wide. Most of the HCV infected patients are unaware of their clinical status and hence the disease may be under reported.

\section{REFERENCES}

1. Shepard CW, Finelli L, Alter MJ. Global epidemiology of hepatitis C virus infection. Lancet Infect Dis 2005;5:558-67.

2. Alter MJ. Hepatitis $C$ virus infection in the United States. J Hepatol 1999;31 Suppl 1:88-91.

3. Hepatitis C: Global prevalence. Wkly Epidemiol Rec 1997;72:341-4.

4. Poovorawan Y, Chatchatee P, Chongsrisawat V. Epidemiology and prophylaxis of viral hepatitis: A global perspective. J Gastroenterol Hepatol 2002;17 Suppl:S155-66.

5. CD Alert. Monthly Newsletter of National Centre for Disease Control, Directorate General of Health Services, Government of India 2007;11:1-4.

6. Irshad M, Joshi YK, Acharya SK, Tandon BN. Prevalence of hepatitis $\mathrm{B}$ virus infection in healthy persons in North India. Natl Med $\mathrm{J}$ India 1994;7:210-2.

7. Jaiswal SB, Chitnis D, Pradeep S, Achal S, Pandit CS. Prevalence of hepatitis viruses among chronic renal failure patients on hemodialysis in central India. Dialysis and Transplantation 2002;31:234-40.

8. Kar P, Budhiraja S, Narang A, Chakravarthy A. Etiology of sporadic acute and fulminant non-A, non-B viral hepatitis in north India. Indian J Gastroenterol 1997;16:43-5.

9. Jindal N, Jindal M, Jilani N, Kar P. Seroprevalence of hepatitis C virus $(\mathrm{HCV})$ in health care workers of a tertiary care centre in New Delhi. Indian J Med Res 2006;123:179-80.

10. Arora DR, Sehgal R, Gupta N, Yadav A, Mishra N, Siwach SB. Prevalence of parenterally transmitted hepatitis viruses in clinically diagnosed cases of hepatitis. Indian J Med Microbiol 2005;23:44-7.

11. Patra S, Kumar A, Trivedi SS, Puri M, Sarin SK. Maternal and fetal outcomes in pregnant women with acute hepatitis $E$ virus infection. Ann Intern Med 2007;147:28-33.

12. Mast EE, Alter MJ, Margolis HS. Strategies to prevent and control hepatitis B and C virus infections: A global perspective. Vaccine 1999;17:1730-3.

13. Recommendations for prevention and control of hepatitis $C$ virus (HCV) infection and HCV-related chronic disease. Centers for Disease Control and Prevention. MMWR Recomm Rep 1998;47:1-39.

14. Das K, Agarwal A, Andrew R, Frösner GG, Kar P. Role of hepatitis E and other hepatotropic virus in aetiology of sporadic acute viral hepatitis: A hospital based study from urban Delhi. Eur J Epidemiol 2000;16:937-40.

15. Kaur R, Gur R, Berry N, Kar P. Etiology of endemic viral hepatitis in urban North India. Southeast Asian J Trop Med Public Health 2002;33:845-8.

16. Ali S, Shukla I, Malik A, Rizvi M, Ajmal MR. Prevalence of HCV and HBV infection in liver disorders in the Aligarh region of western Uttar Pradesh. Indian J Pathol Microbiol 2008;51:460-1.

17. Srikrishna A, Sitalakshmi S, Damodar P. How safe are our safe donors? Indian J Pathol Microbiol 1999;42:411-6.

18. Gupta N, Kumar V, Kaur A. Seroprevalence of HIV, HBV, HCV and syphilis in voluntary blood donors. Indian J Med Sci 2004;58:255-7.

19. EASL International Consensus Conference on hepatitis C. Paris, 26-27 February 1999. Consensus statement. J Hepatol 1999;31 Suppl 1:3-8.

20. Pahuja S, Sharma M, Baitha B, Jain M. Prevalence and trends of markers of hepatitis $C$ virus, hepatitis $B$ virus and human immunodeficiency virus in Delhi blood donors: A hospital based study. Jpn J Infect Dis 2007;60:389-91.

21. Sharma R, Sinha P, Bachiwal R, Rishi S. Seroprevalence of anti hepatitis $C$ virus antibodies in a hospital based population in Jaipur, Rajasthan. Indian J Community Med 2007;32:158-9.

22. Kumar A, Sharma KA, Gupta RK, Kar P, Chakravarti A. Prevalence \& risk factors for hepatitis $\mathrm{C}$ virus among pregnant women. Indian J Med Res 2007;126:211-5.

23. Bhattacharya S, Badrinath S, Hamide A, Sujatha S. Seroprevalence of Hepatitis $C$ virus in a hospital based general population in south India. Indian J Med Microbiol 2003;21:43-5.

24. Chandra M, Khaja MN, Farees N, Poduri CD, Hussain MM, Aejaz Habeeb $\mathrm{M}$, et al. Prevalence, risk factors and genotype distribution of HCV and HBV infection in the tribal population: A community based study in south India. Trop Gastroenterol 2003;24:193-5.

25. Devi KS, Singh NB, Mara J, Singh TB, Singh YM. Seroprevalence of hepatitis $B$ virus and hepatitis $C$ virus among hepatic disorders and injecting drug users in Manipur-A preliminary report. Indian $\mathrm{J}$ Med Microbiol 2004;22:136-7. 
26. Mukhopadhyaya A. Hepatitis C in India. J Biosci 2008;33:465-73.

27. Singh B, Verma M, Verma K. Markers for transfusion-associated hepatitis in north Indian blood donors: Prevalence and trends. Jpn J Infect Dis 2004;57:49-51.

28. Nishioka S, Gyorkos TW. Tattoos as risk factors for transfusion-transmitted diseases. Int J Infect Dis 2001;5:27-34
How to cite this article: Rajani M, Jais M. Age-wise seroprevalence of hepatitis $C$ virus infection in clinically suspected infectious hepatitis patients attending a tertiary care hospital in Delhi. Int J Med Public Health 2014;4:78-81.

Source of Support: Department of Microbiology, Lady Hardinge Medical College, New Delhi., Conflict of Interest: None declared. 